\title{
Scaffolding Pronunciation in Saudi EFL Classroom at Majma'ah University
}

\author{
El-Sadig Yahya Ezza \\ Majma'ah University \\ E-mail: sadigss@yahoo.com
}

Received: 16-02-2013

Accepted: $16-03-2013$

Published: 01-05-2013

doi:10.7575/aiac.ijalel.v.2n.3p.62

URL: http://dx.doi.org/10.7575/aiac.ijalel.v.2n.3p.62

\begin{abstract}
The College of Education at Majma'ah University shifted from King Saud University EFL syllabus to Gassim University EFL syllabus at the second term of the academic year 1432/1433. The new syllabus introduces the students to the English pronunciation before introducing them to linguistics. Contrary to the general paradigm, this situation is argued to deprive the students from a proper socialization into the academic discourse of linguists that could have otherwise helped them to understand the English phonology. Also, the students' pre-college education trained them to base their English pronunciation on the letters of alphabet despite all the irregularities inherent in the English spelling system. For these reasons, among others, it became necessary to adopt the scaffolding theory as an interventionist teaching strategy to achieve four objectives: to facilitate and enhance the students' understanding of the English pronunciation, to provide them with more opportunities to practise pronunciation, to train them to use authentic pronunciation sources and to help them to become autonomous learners who could actively take responsibility for their own learning.
\end{abstract}

Keywords: pronunciation, accent, scaffolded instruction, sounds, transcription, articulation, mispronunciation, spelling, dictionary, listener-friendly

\section{Introduction}

Pronunciation is such a demanding EFL subject that it is argued to poorly correlate with general language skills, i.e. a learner can be lexically and grammatically competent but phonologically poor (Fraser, 2001, p.35). This argument receives reinforcement from the observation that good pronunciation can be understood even when the speech abounds in errors in other language areas while unintelligible speech cannot be enhanced by "extensive vocabulary and perfect grammar" (Yates and Ziellinski, 2009, p. 11). Also, unlike grammar and vocabulary, pronunciation seems to be the only linguistic factor that differentiates between adult native and non-native speech (Corder, 1971; 1981).

Part of the reason that renders this subject problematic for the specific group of students included in this study is that they were introduced to pronunciation a long time after they had been trained to base it on the letters of alphabet, ignoring the fact that these letters are widely conceived in the relevant literature as an unreliable guide to contemporary English pronunciation (Brook, 1958, p. 100). The students were surprised to realize that there was an acute discrepancy between the vowel letters and vowels sounds to the extent that one of the latters (i.e. the vowel letter "a") could be pronounced in seven different ways: another, act, part, watch, wall, make and area. Unfortunately, the fact that the vowel sounds are embedded in the writing system of the students' $\mathrm{L}_{1}$ made it extremely difficult to facilitate the comprehension of the vowel concept in English by analogy. For these reasons, among others (see 4 below), it became necessary to adopt the scaffolding theory as an interventionist teaching strategy to achieve four objectives: to facilitate and enhance the students' understanding of the English pronunciation, to provide the students with more opportunities to practise pronunciation, to train them to use authentic pronunciation sources and to help them to become autonomous learners who could actively take responsibility for their own learning. This paper, then, sets out to report the specific steps taken to apply scaffolded instruction to achieve the objectives just mentioned. In so doing, it will attempt to answer the following questions:

i. What are the pronunciation difficulties to warrant the use of scaffolds as an interventionist teaching strategy?

ii. What are the scaffolds employed to facilitate the students' comprehension of English course on pronunciation?

iii. How successful is this intervention strategy to overcome problems pertaining the acquisition of English pronunciation?

\section{Theoretical Background}

Pronunciation is an oral skill that functions better if it is "integrated into the ongoing teaching and practicing of speaking skills" (Yates and Zielinski, 2009, p. 11). It consists of a number of processes that range from the production of individual sounds and sound clusters to connected speech with all its prosodic features (e.g. stress, intonation, rhythm, etc). The relevant literature informs that students attending a pronunciation course need not acquire a native 
accent for what matters is the acquisition of intelligible speech (Jones, 1937; Gilbert, 2008; Yates and Zielinski, 2009). Since intelligibility is judged from the listener's perspective, it is proposed that a special attention should be focused "on the development of a pronunciation that is listener friendly" (Gilbert, 2008, p. 1). However, with the present status of English as a world lingua franca, it becomes virtually impossible to train EFL learners to be "comfortably intelligibly", to use Abercrombie's phrase (as quoted in Yates and Zielinski, 2009, p. 12) since English is spoken in different accents at different parts of the world. What is more, applying pronunciation standards that correspond to the different varieties of English could result in a kind of communication chaos; viz. each speech community might insist on its own pronunciation standard and this jeopardizes mutual understanding between the speakers of different English varieties across the world. The rational choice is to accept Widdowson's $(2009$, p. 185) proposal that the standard is set by those who own the language by virtue of "primogeniture and due to birth". This view narrows down the standard to the English accents included in Kashru and Nelson's (1996, p. 78) inner circle of English speakers in Britain, Canada, Australia and New Zealand.

Fraser (2001, p. 7) reports that teachers often conceive of English pronunciation as difficult and frustrating to teach as the relevant teaching approaches are complex, daunting and time-consuming and that the textbooks used in teaching are not student friendly. Where the students are concerned, the relevant literature shows that they undergo three types of problems that are physical, cognitive and social in nature. The physical problems have to do with the articulation of individual sounds and sound clusters. But even when the students can pronounce a given sound, it is argued that they will fail to do so when that same sound appears in unfamiliar position. For instance, while the sounds $/ \mathrm{k} /, / \mathrm{s} /, / \mathrm{t} / \mathrm{and} / \mathrm{r} /$ are produced in Arabic, many Arabic-speaking EFL learners are assumed to experience difficulty in pronouncing them when they occur in such clusters as extra, straight, prompts since they are not allowed in the Arabic phonology (Mohammedein, 2004). Physical problems of pronunciation are also caused by the English prosody. In other words, individual sounds lose their phonemic features owing to the influence of juxtaposing sounds in connected speech. Gilbert $(2008$, p. 7$)$ goes so far as to claim that "prosody distorts sounds so much that they are unrecognizable from the sounds of the word when it is said in isolation".

An alternative explanation to the physical causes of the majority of pronunciation problems is the cognitive causes. It is argued that learners experience such problems because "they do not conceptualize the sounds appropriatelydiscriminate them in their minds, and manipulate them as required for the sound system of English" (Fraser, 2001, p. 20). But how could the speech sounds be conceptualized? In an attempt to answer this question, Fraser proposes that even when learners imitate speech sounds, what they do is more than "a simple parroting exercise, in which the ear picks the sounds and the tongue plays them back" (p. 23). What matters is that these two processes are mediated by conceptualization, i.e. learners subconsciously think about the speech sounds, deconstruct and restructure them according to the English phonotactics (ibid). However, second language acquisition research does not seem to support the "subconscious component" of the cognitive explanatory framework as proposed by Fraser. In principle, "learning" is a conscious process in the sense that "consciousness" is conceived as "attention", intentionality and "awareness"; viz. learners "pay attention to form", "set out to learn some elements deliberately" and " become aware of what they are learning" (Ellis, 2008, p. 434-435)

The social problems of pronunciation have to do with what Lipski (1937, p. 13) terms "deliberate mispronunciation", that results from "a general desire to degrade, belittle, or ridicule members of minority ethnic groups". This interpretation is akin to Arabic native speakers' tendency to legitimize deliberate mispronunciation of foreign names. In other words, the Arabs empower themselves with a "phonological license", so to speak, to pronounce foreign names as they see convenient. It is unfortunate that this culturally-fueled stance could have negative bearing on the acquisition of English pronunciation among Arabic-speaking EFL students. In fact, a Saudi EFL student once contended that it would make no difference to pronounce the English word "child" as /t $\mathrm{faild} /$ and /t $\mathrm{f}$ ild/.

Given all the problems inherent in the teaching and acquisition of English pronunciation, it was reported in (1) above that an attempt had been made to use scaffolding theory as an intervention strategy to enhance the students' comprehension of the course materials. In that connection, it is convenient to review the literature pertaining to this theory before proceeding to report its applications in the classroom.

To begin with, "scaffolding" is conceived as a social interaction process initiated by experts to create "supportive environments for novices to acquire knowledge at a higher competency level" (Vygotsky, 1978; as quoted in Pawan, 2008, p. 145) Thus, through scaffolded instruction learners can operate within Vygotsky's Zone of Proximal Development (ZPD), i.e. the area between what they can perform without assistance and the level at which they can perform with assistance. According to the Faculty Development and Instructional Design Center at North Illinois University, a scaffolded- instruction benefits the students in at least seven ways:

- Challenges the students through deep learning and discovery.

- Engage the students in meaningful and dynamic discussions in small and large groups.

- Motivates learners to become better students (learning to learn)

- Increases the likelihood for students to meet instructional objectives.

- Provides individualized instruction.

- Affords the opportunity for peer-teaching and learning.

- Provides a welcoming and caring learning environment. (p. 5) 
But what specific scaffolds should teachers apply to facilitate learning for the students? The relevant literature abounds in a variety of scaffold types that teachers can employ to serve this purpose. For instance, Pawan (2008, p. 1454) identifies four scaffolds that can provide "content area teachers (CATs) with an effective means to integrate language instruction into area construction for English language learners...). These include linguistic scaffolding (i.e. use of simple English to facilitate subject comprehension), conceptual scaffolding (i.e. use of organizational charts to illustrate new concepts), social scaffolding (i.e. group work and peer teaching) and cultural scaffolding (i.e. use of tools related to students' culture to explain and illustrate course contents). Another such scaffolding model is proposed by Walqui (2006, p. 170-174), which consists of five scaffolds: modeling (i.e. use of previous success model for imitation by the students), bridging (i.e. relating new concepts to existing knowledge), contextualizing (i.e. embedding abstract academic discourse into a comprehensible sensory context using pictures, figures, etc.), schema building (i.e. organizing knowledge into mental themes) and text re-presenting (i.e. transforming constructions from one genre into another). The faculty Development and Instructional design Center at Northern Illinois University uses a more comprehensive scaffolding model that includes, interalia, advance organizers, cue cards, concept and mind maps, examples, handouts and prompts. The need for such a model emanates from the fact that a "more complex content might require a number of scaffolds given at different times to help the students master the content" (p.2). Despite the differences in the number and types of scaffolds just reported, the three scaffolding models agree that academic discourse used in teaching and resourcing is of a complex and abstract nature that can best be made comprehensible through simplification and illustration.

\section{Scaffolding Pronunciation at Majma'ah University}

The course associated with this study is entitled "[P]ronunciation"; it is offered at the second term of the first year at Community College of Majma'ah University. It aims at introducing the students to the phonetic terms, description of the organs of speech, places of articulation, manners of articulation and voicing. It also trains the students in phonetic transcription, syllable identification and stress placement. As to the course resourcing, the third edition of Roach (2000) was prescribed by the syllabus designer to be the basis of teaching. The right-hand column of table (1) below reports the chapters that could be covered to meet the course objectives.

This section attempts to give detailed answers to the research questions that are posed in (1) above regarding the pronunciation difficulties experienced by the students, the nature of scaffolds employed and the degree of success of scaffold-related teaching strategy:

i. What are the pronunciation difficulties to warrant the use of scaffolds as an interventionist teaching strategy?

Generally speaking, there are four reasons that are argued to complicate the students' attempt to understand the mechanism underlying the acquisition of English pronunciations. First, the vast majority of the students could not correctly pronounce mono-syllabic words that were specially employed in the first class to assess their pronunciation competence. All in all, the students' phonological competence was characterized by a tendency to pronounce every letter in the words selected for this purpose so that these forms were produced: /təhi/ for "the", /kımi/ for "come", /bibli/ for "people", etc. Also, it was virtually impossible for all the students to pronounce a consonant cluster consisting of two sounds without inserting a vowel sound between them as illustrated by the pronunciation of the word "the" above. Furthermore, there was no successful attempt to pronounce the course title; however, some of them made it towards the closing weeks of the term following intensive practice in phonetic transcription and syllable identification.

Second, it became apparent that the textbook prescribed as a main source for the course (i.e. Roach, 2000) was far beyond the current level of the students' comprehension. It uses a highly technical vocabulary that has never been part of their lexical repertoire (bearing in mind that they suffer from acute lexical deficiency as indicated by their inability to read simple, mono-syllabic words as shown above). What is more, the textbook was argued to emphasize the acquisition of phonetic information pertaining to phonetic rules and sound production, perception and classification (Ezza and Saadeh, 2011). Thus, it seems virtually impossible that the students can be sufficiently trained to practice English pronunciation owing to the emphasis the textbook places on phonetic information.

Third, the students have never been previously introduced to human language (i.e. linguistics), which could have otherwise socialized them into the academic discourse of linguists. Acquisition of such a discourse is conceived to enable beginning academicians to fully function as members of a given discourse community by adhering to the "rigid conventions for language use, in the choice of words, genre and style" (White and Lowenthal, 2011, p. 7). By contrast, "ignorance and resistance to academic discourse" result in depriving these students from academic success (ibid). It was unfortunate, therefore, that this course was the first venue where the students were both to experience socialization into linguistic discourse and be apprenticed into English pronunciation.

Fourth, the syllabus is fraught with standard-related problems. In other words, while the basic source of the course clearly informs that it is modeled on BBC pronunciation (Roach, 2000, p. vii), other related courses in the syllabus (i.e. listening and speaking) employ textbooks modeled on American pronunciation (i.e. the Interaction series of McGrawHill Education). Apparently, this fact does not follow from the generally held belief that pronunciation could best be taught as an attribute of speaking since acquisition of British accent could not be expected to serve the teaching of American speech.

For all these reasons, scaffolding theory was taken refuge into as an interventionist teaching strategy to achieve the four objectives mentioned in (1) above. This in turn leads to the second question that this study attempts to answer is: 
ii. What are the scaffolds employed to facilitate the students' comprehension of English course on pronunciation?

A modified version of Pawan (2006) and Walqui's (2008) models of scaffolding was used to serve the purpose of this course. It consists of simplification and conceptual scaffolding. As to the first scaffold, an attempt was made to restructure the course content into smaller digestible units instead to the monolithic, information-condensed chapters of Roach (2000) as shown in table (1) below - of course, without sacrificing the amount of information needed to train the students to be future linguists. For instance, the "organs of speech", "places of articulation" and "manners of articulation" were presented separately in the course to facilitate the students' comprehension of their content rather than subsuming them under one topic in Roach (2000), i.e. "Production of Speech". In addition to this procedure of content simplification, and given the fact that the students had not been previously introduced to linguistics, a relatively simple classroom discourse was used for more learning facilitation and enhancement. This teaching strategy involved slow presentation, digression to explain related linguistic topics and bilingual definition of new concepts.

New sections such as letter-sound relationship and problematic consonants and vowel letters were foregrounded in the course to draw the students' attention to the complexities involved in the English pronunciation and, thus, to emphasize the significance of the course in resolving them. Moreover, ample time was devoted to phonetic transcription using the dictionary and a number of online resources. It was realized that the vast majority of the students had never been previously trained to use the dictionary. So in addition to acquiring authentic pronunciation, these resources helped the students to be responsible for their own learning. The integration of the dictionary and the online resources was assumed to overcome the problem inherent in the acquisition of individual sounds. In other words, it is argued that the dictionary pronunciation does not help in grasping actual speech owing to the dramatic sound changes caused by the prosody (Gilbert, 2008, p. 1). One way to handle such a situation was to fall back on online, native pronunciation which provides sufficient practice using words, sentences and even whole texts. BBC learning English proved to be highly relevant and useful in providing authentic pronunciation pertaining to both standard and everyday (slangy) English.

Table 1. Simplification of the course content

\begin{tabular}{|l|l|}
\hline Materials selected for the course & Topics included in Roach (2000) \\
\hline International Phonetic Alphabet (IPA) & Production of Speech \\
\hline Remarks on the Letter-Sound Relationship & Long Vowels and Diphthongs \\
\hline Pronunciation of the English Letters of Alphabet & Voicing and Consonants \\
\hline Problematic areas: consonants & The phoneme \\
\hline Problematic areas: vowels & Fricatives and Affricates \\
\hline Problematic Areas: Diphthongs & The Syllable \\
\hline Organs of Speech & Stress \\
\hline Places of Articulation & \\
\hline Manners of Articulation & \\
\hline Voicing & \\
\hline Use of Dictionary for Pronunciation & \\
\hline Use of online resources & \\
\hline Phonetic Transcription: monosyllabic words & \\
\hline Phonetic Transcription: polysyllabic words & \\
\hline Phonetic Transcription: phrases and short & \\
\hline Syllable and stress & \\
\hline
\end{tabular}

Conceptual scaffolding was richly employed to organize and simplify a plethora of phonetic information as shown in tables (2), (3) and (4) below. Almost all the course content was presented in tabular and graphic forms to summarize given phonetic information, e.g. consonants and vowels, places of articulation, manners of articulation, syllable structure, etc. This visual presentation of a highly technical text renders it more "accessible and engaging for the students" (Walqui, 2006, p.173).

Table 2. Consonants

\begin{tabular}{|l|l|}
\hline Sound & Examples \\
\hline$/ \mathrm{p} /$ & pull, pliers, pen, open, speak, apart, stop, shop, hope, rope \\
\hline$/ \mathrm{b} /$ & bad, book, boy, mobile, robe, able, rob, bulb, cube, blab \\
\hline$/ \mathrm{t} /$ & tide, top, tear, bottom, stop, butter, start, cart, matter, mute \\
\hline$/ \mathrm{d} /$ & Drive, dye, dusk, duty, sudden, body, address, mad, kind, ride \\
\hline$/ \mathrm{k} /$ & character, quite, cook, sick, like, quick, clinic, cry, ache, break \\
\hline$/ \mathrm{g} /$ & go, get, green, ego, again, ago, ignore, leg, big, drag \\
\hline$/ \mathrm{t} /$ & chair, child, change, recharge, luncheon, butcher, lynch, pitch, inch, rich \\
\hline$/ \mathrm{d} /$ & judge, jury, gym, lodge, injure, page, jump, giraffe, gibber, genus \\
\hline
\end{tabular}


Table 3. Vowels

\begin{tabular}{|l|l|}
\hline Sound & Examples \\
\hline /i/ & it, ill, erode, exempt, live, pink, hill, sit, city, holly \\
\hline /i:/ & eve, aegis, easy, estrogen, seat, precede, receive, fee, sea, see \\
\hline /e/ & enter, else, epic, essay, bed, red, set, let, step, help \\
\hline /3:/ & early, oeuvre, urgent, urge, urban, learn, word, girl, world, burn \\
\hline$/ \Lambda /$ & up, unrest, under, thunder, cut, shut, much, skull, hut, thumb \\
\hline /ə/ & another, aback, abase, ahead, perceive, open, water, governor, later \\
\hline /æ/ & abstract, act, add, adequate, ash, cat, drag, fat, hat, sad \\
\hline$/$ a:/ & art, arch, argue, ask, answer, dark, shark, smart, mark, cart \\
\hline
\end{tabular}

Table 4. letter-sound relationship (vowels)

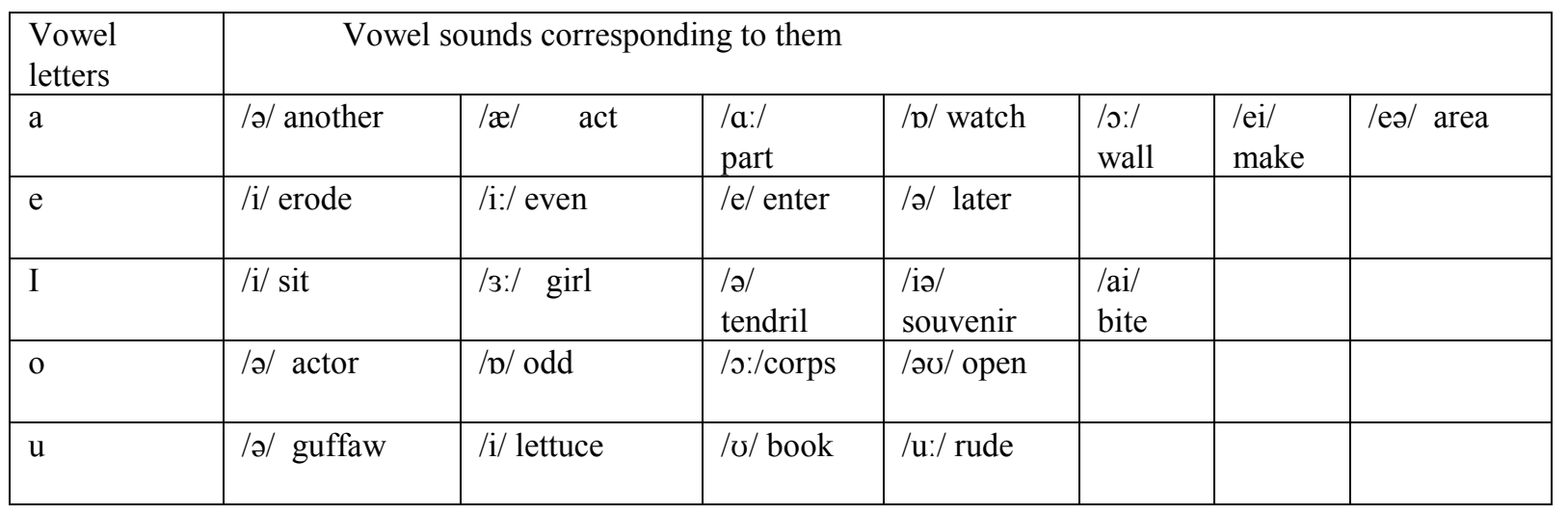

As shown in tables (2) and (3), each sound was exemplified with ten words with the prime objective of inculcating the English sound concept into the students' minds given the observation made in (1) above that they had for a long time been trained to base their pronunciation of English on the letters of the alphabet. Of course, they were also pressurized to learn more English words. An attempt was made to use short words (mostly monosyllabic and bi-syllabic words) that the students could pronounce more easily. Special attention was paid to the occurrence of the sounds word-initially, word-medially and word-finally as a prelude to future classes on the English phonotactics.

iii. How successful was the scaffolded instruction in facilitating the students' comprehension of the English pronunciation?

The students' satisfaction was one way to assess the usefulness of the scaffolded instruction as described in this study. In so doing the students were asked to complete a customer satisfaction form devised by the Deanship of Quality Assurance at Majma'ah University. The form consists of three open-ended questions concerning the strengths, weakness and proposals for the improvement of the service being offered. Answers could be given in English, Arabic or bilingually as the student sees convenient. The students were informed that there would no reward for any attempt to please the teacher, and to guarantee that they speak their minds; it was emphasized that any form including a student's name would be discarded. Out of the total of fourteen students enrolled for the course, the six most regular attendees participated in the assessment of the course instruction. Table (4) below summarizes their feedback:

Table 4. Participants' Feedback

\begin{tabular}{|l|l|l|}
\hline Strengths & weaknesses & Proposals for Improvement \\
\hline $\begin{array}{l}\text { Intensive pronunciation practice. } \\
\text { Multiple quizzes. }\end{array}$ & $\begin{array}{l}\text { Insufficient practice in } \\
\text { vowel pronunciation. } \\
\text { Content simplification. }\end{array}$ & $\begin{array}{l}\text { More summary of the course } \\
\text { content } \\
\text { Summary of the course content. } \\
\begin{array}{l}\text { Use of sufficient examples to } \\
\text { illustrate different sounds }\end{array}\end{array}$ \\
& & $\begin{array}{l}\text { More practice in vowels' } \\
\text { pronunciation } \\
\text { Preparation of handouts, } \\
\text { summarizing the content of } \\
\text { different components }\end{array}$ \\
& & $\begin{array}{l}\text { Fixing one class for weekly } \\
\text { revision } \\
\text { More assignments } \\
\text { Regular discussion about the } \\
\text { students progress. } \\
\text { More group work. }\end{array}$ \\
& & More homework. \\
\hline
\end{tabular}


There are two remarks to be made about the students' feedback. First, they reported that there had been insufficient practice in the pronunciation of vowels despite the fact that about 300 words were used to illustrate their different occurrences, i.e. word-initially, word-medially and word-finally. They also reported that there had been insufficient assignments although ten different sound identification exercises were used to familiarize the students with the English sounds. Furthermore, whole stanzas of the well-known poem "English is a Tough Stuff" were read aloud and transcribed to acquaint the students with confusing nature of the English spelling system and the extent to which it can be cleared up with the study of the English phonology, e.g.

Dearest creature in creation

Studying English pronunciation,

I will teach you in my verse

Sounds like corpse, corps, horse and worse.

I will keep you, Susy, busy,

Make your head with heat grow dizzy;

Tear in eye, your dress you'll tear;

Queer, fair seer, hear my prayer.

Second, most students doing English were generally conceived to have a pragmatic approach to education; viz. they were more concerned with the end product (good grades, accumulative average, degree, etc.) than with the process leading to it (cf. Ezza, 2012). However, the participants' feedback regarding the proposals for teaching improvement indicates that they were aware of the significance of academic development as shown by their emphasis on the weekly revision of the course content, regular assessment of their progress and group work.

\section{Conclusion}

Commenting on Ezza (2012), some audience at the Tenth International Conference of Asia TEFL in Delhi, India were astounded to know that first year students at Majma'ah University were required to study Roach (2000) as a basic resource for a course on English pronunciation, bearing in mind that they had not been previously introduced to linguistics. Part of the difficulty inherent in this textbook is that it uses a highly technical vocabulary that is far beyond the students' lexical reservoir. This fact adds insult to injury since the students were not only required to study Roach (2000) but also had to make a heightened effort to decipher a complex academic discourse that they encountered for the first time in their tertiary socialization. Therefore, taking refuge into student-friendly teaching strategies would become a matter of academic urgency to facilitate learning for the students. Fortunately, scaffolded instruction is globally acknowledged as a successful intervention strategy that not only enable the students to take responsibility for their own learning but also become autonomous learners. As shown above, the students enrolled for this course were trained in the dictionary use and were introduced to some useful websites to provide them with authentic native pronunciation. These two resources will eventually be available for further use after the completion of the course requirements so that the students can consult at their own pace.

\section{References}

Brook, G. L. (1958). A History of the English Language. London: Andre Deutsche.

Corder. S. P. (1971). Idiosyncratic Dialects and Error Analysis. International Review of Applied Linguistics in Language Teaching, 9(2), 147-160.

Corder. S. P. (1981). Error Analysis and Interlanguage. Oxford: Oxford University Press.

Ellis, R. (2008). The Study of Second Language Acquisition, $2^{\text {nd }}$ ed. Oxford: Oxford University Press.

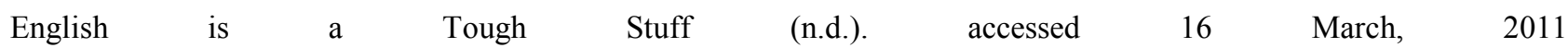
http://www.frivolity.com/teatime/Songs_and_Poems/english_is_tough_stuff.html

Ezza, S. Y. and Z. Saadeh (2011). Dictionary as a Basic Resource for English Pronunciation. World Journals of English Language, 1(1), 63-67.

Ezza, S. Y. (2012a). Intervention Strategies in Saudi EFL Classroom. A paper presented at KSAALT Fifth Conference, Effat University, Jeddah, Saudi Arabia.

Ezza (2012b). Scaffolded Pronunciation Instruction in Saudi EFL Classroom at Majma'ah University. A paper presented at Asia TEFL $10^{\text {th }}$ International Conference, Delhi, India.

Instructional Scaffolding to Improve Learning (n.d.). Northern Illinois University, Faculty Development and Instructional Design Center at North Illinois University. Retrieved 23 July, 2012 from www.niu.edu/facdev. 815.753 .0595

Fraser, H. (2001). Teaching Pronunciation: A handbook for Teachers and Trainers. Sydney: New South Wales department of Education and Training.

Gilbert, J. B. (2008). Teaching Pronunciation, Using the Prosody Pyramid. Cambridge: Cambridge University Press. 
Jones, D. (1937, April-June). On Received Pronunciation. Supplement to Le Maitre Phonetique, 107-108.

Kashru, B. B. and C. L. Nelson (1996). World Englishes. In S. L. McKay and N. H. Hornberger (eds.): Sociolinguistics and Language Teaching. 71-102. Cambridge: Cambridge University Press.

Lipski, J. M. (1976). Prejudice and Pronunciation. American Speech, 51(12), 109-118.

Mohammedein, M. Y. (2004). Pronunciation Difficulties Experienced Sudanese Learners of EFL: Contrastive Investigation of Phonemic and Phonotactic Structures. Unpublished Ph.D. Thesis, University of Khartoum.

Pawan, F. (2008). Content-area Teacher and Scaffolded Instruction for English Language Learners. Teaching and Teacher Education, 24, 1450-1462

Pronunciation Tips (2012, November). BBC: Learning English. Retrieved from http://www.bbc.co.uk/worldservice/learningenglish/grammar/pron/sounds/

Roach, P. (2000). English Phonetics and Phonology: A practical course, $3^{\text {rd }}$ ed. Cambridge: Cambridge University Press.

Walqui, A. (2006). Scaffolding Instruction for English Language Learners: A Conceptual Framework. The International Journal of Bilingua Education and Bilingualism, 9(2), 159-180.

White, J. W. and P. R. Lowenthal (2011). Minority College Students and Tacit "Codes of Power": Developing Academic Discourse and Identities. The Review of Higher Education,34(2), 283-318.

Widdowson, H. (2009). The Ownership of English. In J. Jenkins (ed.): World Englishes, $2^{\text {nd }}$ Edition, 184-189. Oxon: Routledge.

Yates, L and B. Ziellinski (2009). Give it a Go: Teaching Pronunciation to Adults. Sydney: AMEP Research Centre 